University of Nebraska - Lincoln

DigitalCommons@University of Nebraska - Lincoln

\title{
Multiple virus infections in the honey bee and genome divergence of honey bee viruses
}

\author{
Yanping Chen \\ USDA-ARS \\ Yanping Zhao \\ USDA-ARS, zhaoy@ba.ars.usda.gov \\ John Hammond \\ USDA-ARS \\ Hei-ti Hsu \\ USDA-ARS \\ Jay Evans \\ USDA-ARS
}

See next page for additional authors

Follow this and additional works at: https://digitalcommons.unl.edu/usdaarsfacpub

Part of the Agricultural Science Commons

Chen, Yanping; Zhao, Yanping; Hammond, John; Hsu, Hei-ti; Evans, Jay; and Feldlaufea, Mark, "Multiple virus infections in the honey bee and genome divergence of honey bee viruses" (2004). Publications from USDA-ARS / UNL Faculty. 390.

https://digitalcommons.unl.edu/usdaarsfacpub/390

This Article is brought to you for free and open access by the U.S. Department of Agriculture: Agricultural Research Service, Lincoln, Nebraska at DigitalCommons@University of Nebraska - Lincoln. It has been accepted for inclusion in Publications from USDA-ARS / UNL Faculty by an authorized administrator of DigitalCommons@University of Nebraska - Lincoln. 


\section{Authors}

Yanping Chen, Yanping Zhao, John Hammond, Hei-ti Hsu, Jay Evans, and Mark Feldlaufea 


\title{
Multiple virus infections in the honey bee and genome divergence of honey bee viruses ${ }^{\text {is }}$
}

\author{
Yanping Chen ${ }^{\mathrm{a}, *}$, Yan Zhao ${ }^{\mathrm{b}}$, John Hammond ${ }^{\mathrm{c}}$, Hei-ti Hsu ${ }^{\mathrm{c}}$, Jay Evans ${ }^{\mathrm{a}}$, Mark Feldlaufer ${ }^{\mathrm{a}}$ \\ ${ }^{\text {a } U S D A-A R S ~ B e e ~ R e s e a r c h ~ L a b o r a t o r y, ~ B e l t s v i l l e, ~ M D ~ 20705, ~ U S A ~}$ \\ ${ }^{\mathrm{b}}$ USDA-ARS Molecular Plant Pathology Laboratory, Beltsville, MD 20705, USA \\ ${ }^{c}$ USDA-ARS Floral and Nursery Plants Research Unit, Beltsville, MD 20705, USA
}

Received 17 May 2004; accepted 19 July 2004

Available online 28 September 2004

\begin{abstract}
Using uniplex RT-PCR we screened honey bee colonies for the presence of several bee viruses, including black queen cell virus (BQCV), deformed wing virus (DWV), Kashmir bee virus (KBV), and sacbrood virus (SBV), and described the detection of mixed virus infections in bees from these colonies. We report for the first time that individual bees can harbor four viruses simultaneously. We also developed a multiplex RT-PCR assay for the simultaneous detection of multiple bee viruses. The feasibility and specificity of the multiplex RT-PCR assay suggests that this assay is an effective tool for simultaneous examination of mixed virus infections in bee colonies and would be useful for the diagnosis and surveillance of honey bee viral diseases in the field and laboratory. Phylogenetic analysis of putative helicase and RNA-dependent RNA polymerase (RdRp) encoded by viruses reveal that DWV and SBV fall into a same clade, whereas KBV and BQCV belong to a distinct lineage with other picorna-like viruses that infect plants, insects and vertebrates. Results from field surveys of these viruses indicate that mixed infections of BQCV, DWV, KBV, and SBV in the honey bee probably arise due to broad geographic distribution of viruses.
\end{abstract}

Published by Elsevier Inc.

Keywords: Apis mellifera; Viruses; Coinfection; Multiplex RT-PCR

\section{Introduction}

The honey bee Apis mellifera L. is an important beneficial insect that assists in the pollination of a wide variety of crops with an annual added market value exceeding 15 billion dollars (Morse and Calderone, 2000). However, honey bees are attacked by a myriad of parasites and pathogens including viruses, bacteria, protozoa and parasitic mites. So far, honey bees have

\footnotetext{
Disclaimer: Mention of trade names or commercial products in this article is solely for the purpose of providing specific information and does not imply recommendation or endorsement by the US Department of Agriculture.

Corresponding author. Fax: +1 3015048736.

E-mail address: chenj@ba.ars.usda.gov (Y. Chen).
}

been reported to be the host to at least 18 viruses (Allen and Ball, 1996). Of those viruses infecting honey bees worldwide, acute bee paralysis virus (ABPV), black queen cell virus (BQCV), Kashmir bee virus (KBV), and sacbrood virus (SBV) are the most common infections in the United States. Most honey bee viruses are single stranded RNA viruses. They are isometrical about $20-30 \mathrm{~nm}$ in diameter and nonoccluded possessing a buoyant density in $\mathrm{CsCl}$ ranging from 1.33 to 1.42 $\mathrm{g} / \mathrm{ml}$, and a 100-190S sedimentation coefficient (Bailey, 1976). To date, the complete genome sequences of six bee viruses, ABPV (Govan et al., 2000), BQCV (Leat et al., 2000), DWV (GenBank Accession No.: NC004830), Kakugo virus (KV) (Fujiyuki et al., 2004), KBV (GenBank Accession No.: NC-004807), and SBV (Ghosh et al., 1999) have been reported. The genomes 
of $\mathrm{ABPV}, \mathrm{BQCV}$, and $\mathrm{KBV}$ are monopartite bicistronic with non-structural genes at the $5^{\prime}$ end and structural genes at the $3^{\prime}$ end, while the genome of $\mathrm{KV}, \mathrm{SBV}$ and DWV are monopartite monocistronic genomes with structural genes at the $5^{\prime}$ end and non-structural genes at the $3^{\prime}$ end. Based largely on phylogenetic analyses using these sequences, a new virus family, Dicistroviridae, has been proposed to include several of the honey bee viruses (Mayo, 2002).

In nature, BQCV, DWV, KBV, and SBV infect larvae and pupae as well as adult bees, while ABPV affects only adult bees. Diagnosis of bee virus infections is difficult because honey bee viruses usually persist as inapparent infections and cause no overt signs of disease (Bailey, 1967). In addition, attempts to determine the frequency of viruses in the field have been slowed by the fact that bee colonies can be attacked by more than one virus. Multiple viral infections have been reported in bees by a number of authors including Anderson (1990), Anderson and Gibbs (1988), Benjeddou et al. (2001), Evans (2001), Hung et al. (1996a,b), and Leat et al. (2000). For many years, detection and identification of viral infection in honey bee colonies were based largely on serological methods like Ouchterlony gel diffusion, indirect fluorescent antibody (IFA) and enzyme-linked immunosorbent assay (ELISA) tests (Allen and Ball, 1995; Allen et al., 1986; Anderson, 1984). However, the use of serological methods in virus research is problematic. First, their low specificity can misclassify related viruses (Allen and Ball, 1995; Mansy et al., 1999; Rinderer and Green, 1976). Second, serological assays are also limited by low sensitivity; and they are unable to detect latent infections. Finally, serological techniques require the production and distribution of antibodies, making repeatability across different research groups difficult. The polymerase chain reaction (PCR) assay has revolutionized the diagnosis of virus infection and offers a standard method for the specific and sensitive diagnosis of virus infection. Several studies used a RT-PCR assay to detect and identify virus infections in honey bee colonies (Bakonyi et al., 2002; Benjeddou et al., 2001; Evans, 2001; Grabenstiner et al., 2001; Hung et al., 2000; Ribiere et al., 2002; Stoltz et al., 1995). Nevertheless, single RT-PCR assay allows the detection of only one virus per reaction and detection of mixed virus infections would require several separate RT-PCRs. Hence, the development of a rapid, reliable, reproducible, sensitive, and specific diagnostic assay for simultaneous detection of multiple virus infections in honey bees would be advantageous. Multiplex PCR is a modification of the single PCR method using a single tubePCR amplification in which multiple pairs of primers are used simultaneously. It allows the simultaneous detection of different viruses in a single reaction and can reduce the diagnostic time and costs.
In the present study, virus coinfection in honey bee colonies was investigated. A multiplex RT-PCR assay for simultaneous detection of BQCV, DWV, KBV, and SBV in honey bee samples was developed and the specificity of the multiplex RT-PCR assay for detecting mixed virus infections was evaluated by sequence analysis of individual virus specific PCR fragments. In addition, the morphology of virus particles from the bees was examined by electron microscope with a negative stain method. Further, the phylogenetic relationships of the helicase and RNA-dependent RNA polymerase $(\mathrm{RdRp})$ protein encoded by honey bee viruses and six other positive-strand RNA viruses infecting plants, vertebrates, and other insects were analyzed. To our knowledge, this is the first report on mixed infection of four viruses in honey bees and the first report of the use of multiplex RT-PCR assay for detection of multiple virus infection in honey bee colonies. This work demonstrates the feasibility of multiplex RT-PCR for simultaneous detection of multiple virus infections in the honey bee colonies.

\section{Materials and methods}

\subsection{Collection of bee samples and isolation of total RNA}

Bee samples used for virus screening were collected individually from 56 colonies. Ten brood (immature) and ten adults were collected individually from each colony following the method described previously (Chen et al., 2004). Total RNA was extracted using TRIzol Reagent (RNA extraction kit, Invitrogen, Carlsbad, $\mathrm{CA}$ ) according to the recommendation of manufacturer's protocol. Adult bees and brood from each colony were placed in an Eppendorf tube individually and ground in $500 \mu \mathrm{l}$ of TRIzol reagent. RNA samples were dissolved in DEPC-treated water in the presence of Ribonuclease Inhibitor (Invitrogen, Carlsbad, CA) and stored at $-80^{\circ} \mathrm{C}$ for further analysis.

\subsection{Construction of virus specific primers}

Primers specific for DWV and SBV were designed based on the published nucleotide sequences (DWV Accession No. NC-004830; SBV Accession No. AF09292) in GenBank. The program Primer 3 (http:// www-genome.wi.mit.edu/cgi-bin/primer/primer3_www.cgi) was used to select the primers for each virus. Amplification of $\mathrm{BQCV}$ was performed using the primer pair reported by Benjeddou et al. (2001). For KBV, amplification was conducted using virus specific primer pairs previously designed by Stoltz et al. (1995). Amplification of ABPV was conducted using primer pairs reported by Benjeddou et al. (2001) but no product was 
Table 1

Primers used in the study

\begin{tabular}{|c|c|c|c|}
\hline Primers $\left(5^{\prime}-3^{\prime}\right)$ & Position of the genome & Product size (bp) & Reference \\
\hline 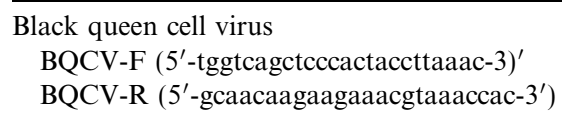 & $\begin{array}{l}7850-8550 \\
\text { (Structure polyprotein) }\end{array}$ & 700 & Benjeddou et al. (2001) \\
\hline $\begin{array}{l}\text { Deformed wing virus } \\
\text { DWV-F }\left(5^{\prime} \text {-cttactctgccgtcgccca- } 3^{\prime}\right) \\
\text { DWV-R }\left(5^{\prime} \text {-ccgttaggaactcattatcgcg- } 3^{\prime}\right)\end{array}$ & $\begin{array}{l}1171-1365 \\
\text { (Structure polyprotein) }\end{array}$ & 194 & This work \\
\hline $\begin{array}{l}\text { Kashmir bee virus } \\
\left.\text { KBV-F (5'-gatgaacgtcgacctattga- } 3^{\prime}\right) \\
\left.\text { KBV-R (5'-tgtgggttggctatgagtca- } 3^{\prime}\right)\end{array}$ & $\begin{array}{l}5405-5820 \\
\text { (Nonstructure polyprotein) }\end{array}$ & 415 & Stoltz et al. (1995) \\
\hline $\begin{array}{l}\text { Sacbrood virus } \\
\text { SBV-F }\left(5^{\prime} \text {-gctgaggtaggatctttgcgt- } 3^{\prime}\right) \\
\text { SBV-R }\left(5^{\prime} \text {-tcatcatcttcaccatccga- } 3^{\prime}\right)\end{array}$ & $\begin{array}{l}\text { 4957-5781 } \\
\text { (structure polyprotein) }\end{array}$ & 824 & This work \\
\hline
\end{tabular}

detected in any of the samples, so we did not include this virus in the study. The primer pairs for each target virus were designed and selected to ensure that the final amplification products of multiplex RT-PCR assay could be differentiated based on their size. The primers used in the study were synthesized by Invitrogen and are shown in Table 1.

\subsection{RT-PCR amplification}

To screen for virus infection in honey bee colonies, RNA samples isolated from adult bees and brood were tested for the presence of BQCV, DWV, KBV, and/or SBV separately by the uniplex RT-PCR. If bees collected from the same colonies had only one detectable virus, the virus status of the colonies was defined as mono-infection. If two, three or four viruses were detected in the bees from the same colonies, the virus status of colonies was considered as dual-infection, triple-infection, and tetra-infection, respectively. Access RT-PCR system (Promega, Madison, WI) was used for RT-PCR according to manufacturer's instructions. Samples were amplified using the PTC-100 DNA Engine (MJ Research, Waltham, MA). The reaction mixture contained: $1 \times \mathrm{AMV} / \mathrm{Tfl}$ reaction buffer, $0.2 \mathrm{mM}$ each $\mathrm{dNTP}, 1 \mu \mathrm{M}$ of sense primer, $1 \mu \mathrm{M}$ of antisense primer, $2 \mathrm{mM} \mathrm{MgSO}_{4}, 0.1$ unit AMV reverse transcriptase, 0.1 unit Tfl DNA polymerase and $500 \mathrm{ng}$ total RNA in a total volume of $25 \mu$. The thermal cycling profiles were as follows: one cycle at $48{ }^{\circ} \mathrm{C}$ for $45 \mathrm{~min}$ for reverse transcription followed by $95^{\circ} \mathrm{C}$ for $2 \mathrm{~min} ; 40$ cycles at $95^{\circ} \mathrm{C}$ for $30 \mathrm{sec}, 55^{\circ} \mathrm{C}$ for $1 \mathrm{~min}$, and $68^{\circ} \mathrm{C}$ for $2 \mathrm{~min}$; $68^{\circ} \mathrm{C}$ for $7 \mathrm{~min}$. Negative and positive controls (previously identified positive sample) were included in each run of RT-PCR. Amplification products were analyzed together with $100 \mathrm{bp}$ ladder for determination of the size of PCR products by electrophoresis through $1 \%$ agarose gel containing $0.5 \mathrm{ug} / \mathrm{ml}$ ethidium bromide and visualized by UV transillumination.

\subsection{Virus purification and electron microscopy}

Honey bees from colonies identified with multiple virus infections were collected for virus purification and electron microscope (EM) study. Thirty bees were frozen in liquid nitrogen and ground to a fine powder and homogenized in $10 \mathrm{ml}$ extraction buffer $(0.1 \mathrm{M}$ potassium phosphate buffer, $\mathrm{pH} 7.5,0.2 \%$ diethyldithiocarbamate, $1 / 5$ volume of diethyl ether). The mixture was emulsified with $5 \mathrm{ml}$ carbon tetracholoride and centrifuged at $3000 \mathrm{~g}$ at $4{ }^{\circ} \mathrm{C}$ for $30 \mathrm{~min}$ to remove the tissue debris. Supernatant containing viruses was centrifuged at 15,000 rpm in a Beckman LB-70M ultracentrifuge, $70.1 / \mathrm{Ti}$ rotor for $2 \mathrm{~h}$ at $4{ }^{\circ} \mathrm{C}$. The pellet was resuspended in $2 \mathrm{ml}$ of $0.2 \mathrm{M}$ PBS buffer and mixed with $\mathrm{CsCl}$ solution to an initial density of $1.37 \mathrm{~g} / \mathrm{ml}$ and centrifuged at $40000 \mathrm{rpm}$ in a Beckman LB-70M ultracentrifuge, $\mathrm{SW} 4 / \mathrm{Ti}$ rotor for $18 \mathrm{~h}$ at $10^{\circ} \mathrm{C}$. The virus-containing band was collected and dialyzed against three changes of $0.1 \times$ PBS over $6 \mathrm{~h}$.

The purified sample was negatively stained and examined for the presence of virus particles in an electron microscope. The presence of viruses in suspension was also confirmed by RT-PCR in parallel using BQCV, DWV, KBV, and SBV specific primers. Virus particles were negatively stained with PTA on a formvar-coated grid and viewed in a JEOL $100 \mathrm{CX}$ electron microscope at magnifications between $33,000 \times$ and $100,000 \times$.

\subsection{Development of the multiplex RT-PCR assay}

In an effort to develop an assay that allowed simultaneous detection of different viruses in a single reaction, multiplex RT-PCR was carried out in the samples of adult bee and brood that were identified with infections of four viruses by uniplex RT-PCR. Multiplex RT-PCR assay was performed using a one-step RT-PCR kit (Promega, Madison, WI). The reaction mixture consisted of $1 \times \mathrm{AMV} / \mathrm{Tfl}$ reaction buffer, $4 \mathrm{mM} \mathrm{MgSO}_{4}, 0.6 \mathrm{mM}$ 
dNTP, 0.4 unit AMV reverse transcriptase, 0.4 unit Tfl DNA polymerase, $2 \mu \mathrm{g}$ total RNA, $0.6 \mu \mathrm{M}$ of each specific primer for $\mathrm{BQCV}, \mathrm{DWV}, \mathrm{KBV}$, and $\mathrm{SBV}$ in a total volume of $50 \mu \mathrm{l}$. The cycling conditions consisted of one cycle at $48{ }^{\circ} \mathrm{C}$ for $45 \mathrm{~min}$ for reverse transcription followed by one cycle at $94{ }^{\circ} \mathrm{C}$ for $2 \mathrm{~min}, 20$ cycles of $94{ }^{\circ} \mathrm{C}$ for $30 \mathrm{~s}, 58^{\circ} \mathrm{C}$ for $1 \mathrm{~min}$, and $68^{\circ} \mathrm{C}$ for $1 \mathrm{~min}$, and 20 cycles of $94{ }^{\circ} \mathrm{C}$ for $30 \mathrm{~s}, 52^{\circ} \mathrm{C}$ for $1 \mathrm{~min}$ and $68^{\circ} \mathrm{C}$ for $1 \mathrm{~min}$ followed by final elongation step at $68^{\circ} \mathrm{C}$ for $10 \mathrm{~min}$. To ensure the absence of contamination, a negative control was included in each reaction run. Since none of the colonies were previously found to be infected with four viruses, a positive control for multiplex assay was not available to include in the reaction. PCR products were separated by electrophoresis in $1.8 \%$ agarose gel and visualized under UV light.

\subsection{Specificity of multiplex $R T-P C R$ assay}

The specificity of multiplex RT-PCR assay was evaluated by sequence analysis of size specific amplification products. Multiplex RT-PCR bands for BQCV, DWV, $\mathrm{KBV}$, and SBV were excised from the low melting agarose gel (Invitrogen, Carlsbad, CA) and purified using Wizard PCR Prep DNA Purification System (Promega, Madison, WI). Purified RT-PCR fragments were individually ligated into a TOPO cloning vector (Invitrogen, Carlsbad, CA). Recombinant plasmid DNAs were purified using Plasmid Mini Prep Kit (Bio-Rad, Hercules, CA). The nucleotide sequences of the cloned RT-PCR fragments were determined using Applied Biosystems DNA Sequencer (Model 3100) from both forward and reverse directions. The sequence data of each virus fragment was analyzed using the BLAST server at the National Center for Biotechnology Information, NIH.

\subsection{Phylogenetic analysis}

To understand the phylogenetic relationship of bee viruses, sequences corresponding to amino acids of the helicase and RdRp domain were used to create phylogenetic trees. In addition, amino acid sequences of helicase and RdRp from six other positive strand RNA viruses infecting plants, insects, and vertebrates were included in the phylogenetic analysis. Initial searches for helicase and RdRp sequences were performed using BLAST. The sequences were analyzed and aligned with the MegAlign (DNASTAR Lasergene software program, Madison, WI). Aligned sequences were imported into the phylogenetic analysis program PAUP 4.03 (Sinauer Associates, Sunderland, MA). Maximum Parsimony under a heuristic search was used to construct the phylogenetic relationship of bee viruses. The equivalent sequences of the Foot-and-Mouth Disease Virus was used as an outgroup. Phylogenies were assessed by the bootstrap replication ( $N=100$ replicates). Bootstrap values of $>50 \%$ were regarded as providing evidence for the phylogenetic grouping.

\section{Results}

\subsection{Mixed virus infections in the bee colonies}

Uniplex RT-PCR was carried out with each of the primer pair specific to BQCV, DWV, KBV, and SBV and generated PCR fragments of 700, 194, 415, and $824 \mathrm{bp}$, respectively. Single or mixed virus infections were detected in adult worker bees and brood collected from colonies. Multiple viruses could be detected in a single bee, or different viruses in individual bees of the same colonies. Out of fifty-six colonies examined, 75\% $(42 / 56)$ colonies were found to be infected with one or more than one virus although tested bees rarely had overt symptoms of infection. Of colonies with virus infection(s), 38\% (16/42) colonies had mono-infection of BQCV, DWV, KBV, or SBV, $50 \%$ (21/42) colonies had dual-infection, 7\% (3/42) colonies had triple-infection, and 5\% (2/42) colonies had tetra-infection (Table 2). The combination of DWV and BQCV infections was observed with the highest frequency $(43 \%, 18 / 42)$ among colonies with virus infections (Table 2).

\subsection{Morphology of bee viruses under electron microscope}

The bee viruses examined have are spherical to slightly ovoid particles about $29 \mathrm{~nm}$ in diameter as determined from EM (Fig. 1). The virus preparation used for EM analysis was determined to contain four different viruses, BQCV, DWV, KBV, and SBV. No significant differences in virion size and morphology could be observed among the virus particles that comprised the four different viruses.

\subsection{Development of multiplex RT-PCR assay}

Total RNAs extracted from bees identified with BQCV, DWV, KBV, and SBV coinfections by uniplex RT-PCR were used for development of the multiplex RT-PCR assay. In order to establish the best conditions for multiplex RT-PCR, preliminary experiments were conducted to optimize several important parameters, including the concentrations of dNTP $(0.2-0.8 \mathrm{mM})$, reverse transcriptase ( $0.5-2$ unit), polymerase ( $0.5-2$ unit), $\mathrm{MgSO}_{4}(1.5-4 \mathrm{mM})$; annealing temperature $\left(50-60^{\circ} \mathrm{C}\right)$; and PCR cycles ( $30-45$ cycles). The final optimum reaction mixture consisted of $4 \mathrm{mM} \mathrm{MgSO}_{4}, 0.6 \mathrm{mM}$ dNTP, 0.4 unit reverse transcriptase, 0.4 unit polymerase, $2 \mu \mathrm{g}$ RNA sample, and $0.6 \mu \mathrm{M}$ of each specific primer for $\mathrm{BQCV}, \mathrm{DWV}, \mathrm{KBV}$, and $\mathrm{SBV}$ in a total volume of $50 \mu \mathrm{l}$. 
Table 2

Investigation of virus infections in honey bee colonies

\begin{tabular}{llll}
\hline Type of infection & Detected viruses & Bee stages detected with virus & $\%$ of colonies with infection(s) $(N=42)$ \\
\hline Mono-infection & BQCV & Adult bee and Brood & $12 \%(5 / 42)$ \\
& DWV & Adult bee and Brood & $12 \%(5 / 42)$ \\
& KBV & Adult bee and Brood & $12 \%(5 / 42)$ \\
& SBV & Adult bee and Brood & Total: $38 \%(16 / 42)$ \\
Dual-infection & BQCV/DWV & & $43 \%(18 / 42)$ \\
& SBV/DWV & Adult bee and Brood & $5 \%(2 / 42)$ \\
& BQCV/SBV & Adult bee and Brood & $2 \%(1 / 42)$ \\
Triple-infection & KBV/DWV/SBV, & Brood & Total: $50 \%(21 / 42)$ \\
& DWV/BQCV/SBV & & $2 \%(1 / 42)$ \\
KBV/BQCV/SBV & Adult bee and Brood & $2 \%(1 / 42)$ \\
Tetrainfection & Adult bee and Brood & Total: $7 \%(3 / 42)$ \\
\hline
\end{tabular}

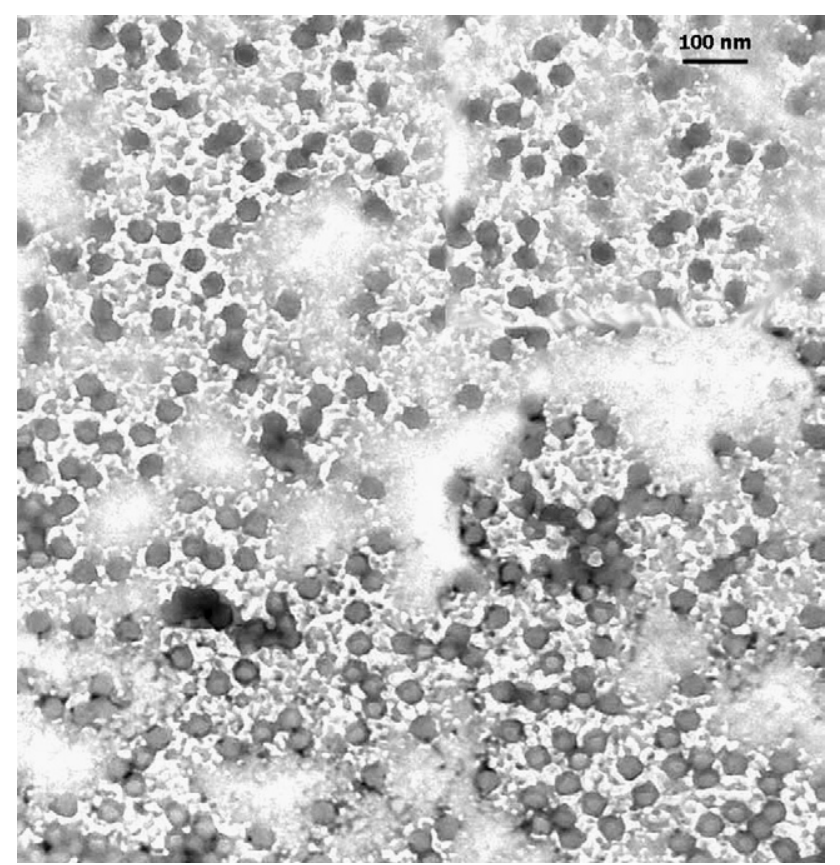

Fig. 1. Electron micrograph of virus particles. Bee viruses are spherical to slightly oval particles about $29 \mathrm{~nm}$ in diameter as determined from EM. No significant difference in the virion size and morphology could be observed among the virus particles in a preparation containing four different viruses. Bar marker represents $0.1 \mu \mathrm{M}$.

The multiple RT-PCR assay was able to detect all four viruses simultaneously in one reaction tube. The results of the multiplex RT-PCR for virus detection were consistent with the result of the uniplex RT-PCR assays. As shown in Fig. 2A and B, PCR products of the expected size for BQCV, DWV, KBV, and SBV were amplified separately by uniplex RT-PCR or simultaneously by multiplex RT-PCR in adult bee and brood that were collected from two different colonies. No amplification product was detected in the negative control. There were variations in band intensity among four

\section{A: Uniplex RT-PCR}

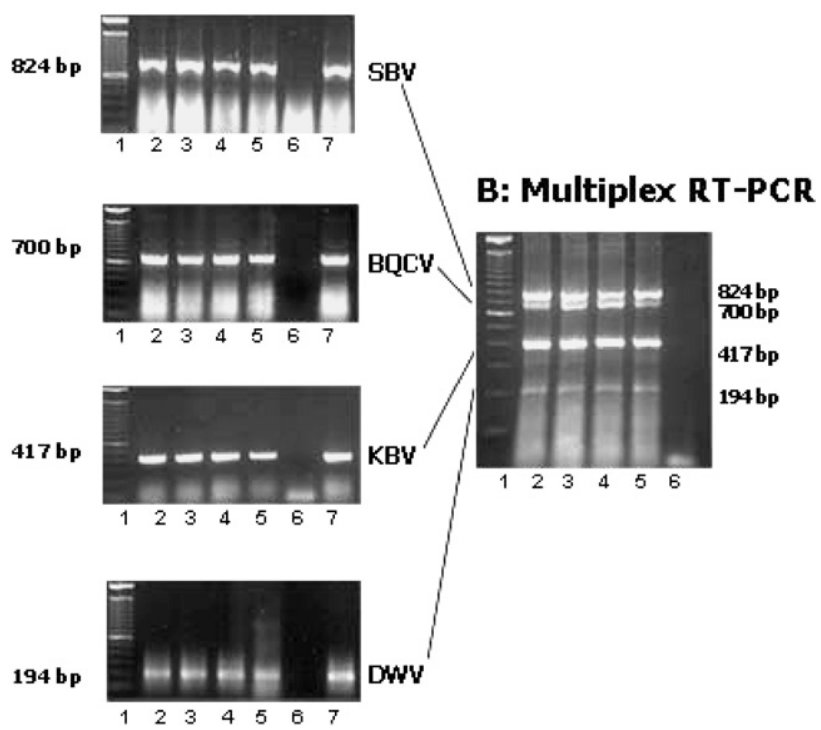

Fig. 2. Detection of virus co-infection in representative honey bee colonies. (A) Amplification of the BQCV, DWV, KBV or SBV by uniplex RT-PCR individually. (B) Amplification of the BQCV, DWV, $\mathrm{KBV}$, and SBV by multiplex RT-PCR simultaneously. For (A), primer pairs specific for BQCV, DWV, KBV, and SBV were used separately, and for (B), in combination to amplify PCR products of 700, 194, 417, and $824 \mathrm{bp}$, respectively. For both (A) and (B), lane 1, $100 \mathrm{bp}$ DNA ladder; lanes 2 and 3, RNA isolated from brood and adult bee of colony (A); lanes 4 and 5, RNA isolated from brood and adult bee of colony (B); lane 6, negative control; and lane 7, positive control (only in uniplex RT-PCR).

PCR fragments that yielded from both multiplex RTPCR and uniplex RT-PCR assays. The amplification band that was specific for KBV had the highest band intensity whereas the band representing the DWV infection had the weakest band intensity.

Specificity of the multiplex RT-PCR was confirmed by the nucleotide sequence analysis of individual PCR fragments. Sequence alignment of amplification 
fragments of each virus with published sequences at the GenBank resulted in 98\% sequence identity for KBV, $92 \%$ for SBV, $97 \%$ for BQCV, and $100 \%$ for DWV.

\subsection{Phylogenetic relationship of honey bee viruses}

Multiple alignments of the putative amino acid sequences of virus-encoded helicase and $\mathrm{RdRp}$ were conducted. As shown in Fig. 3A and B, all compared viruses displayed high levels of sequence similarity for both helicase and RdRp, though RdRp was more conserved than helicase. Phylogenetic consensus trees derived from sequence alignments of the helicase and RdRp were constructed after bootstrapping. Phylogenetic trees that were generated from both helicase and $\mathrm{RdRp}$ alignment yielded a similar result (Fig. 4A and B). DWV, KV, and SBV formed a group with bootstrap values equal to $72 \%$ for helicase and $97 \%$ for $R d R p$.
DWV and KV were more related to one another than to SBV in the group. ABPV, KSV, and BQCV formed a separate group along with Drosophila $\mathrm{C}$ virus (DCV), cricket paralysis virus (CPV), aphid lethal paralysis virus (ALPV), Triatoma virus (TV), and broad bean wilt virus (BBWV).

\section{Discussion}

In the field, honey bee colonies can suffer from multiple virus infections without showing obvious pathological symptoms, thereby confounding diagnoses. A rapid and accurate diagnosis for virus infection, therefore, is a critical component of honey bee disease surveillance and control programs. Multiplex RT-PCR assays have been widely used for virus detection in plants and animals since its first description by Chamberlain et al.

\section{A: Sequence Alignment of Putative Helicase Domain of Viruses}

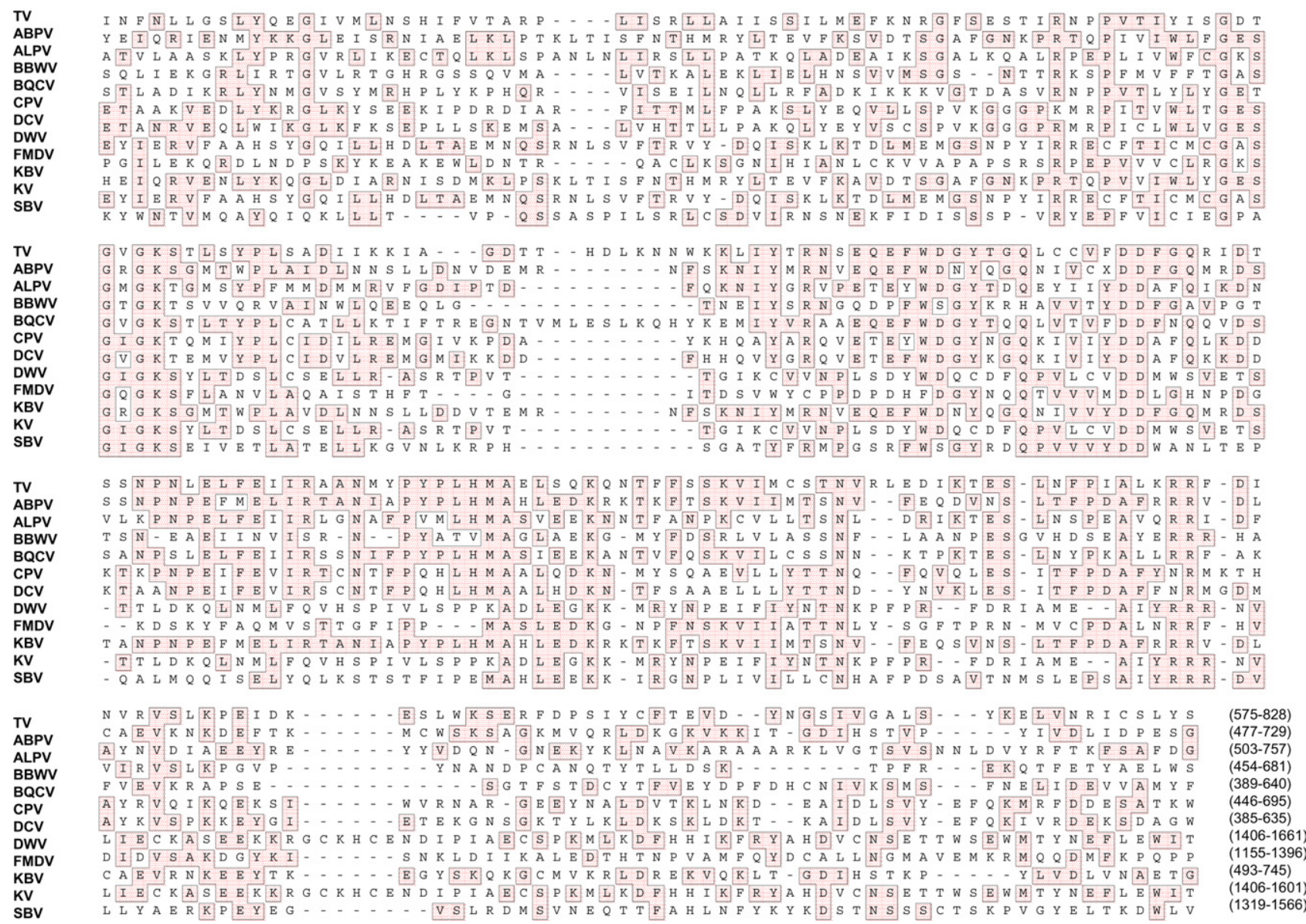

Fig. 3. Multiple amino acid sequence alignment of putative RNA helicase and RNA-dependent RNA polymerase (RdRp) domains of the bee viruses and related viruses. For both (A) and (B), the names of viruses are abbreviated as follows: TV, Triatoma virus; ABPV, acute bee paralysis virus; ALPV, aphid lethal paralysis virus; BBWV, broad bean wilt virus; BQCV, black queen cell virus; CPV, cricket paralysis virus; DCV, Drosophila C virus; DWV, deformed wing virus; FMDV, food-and-mouth disease virus; KBV, Kashmir bee virus; KV, Kakugo virus; and SBV, sacbrood virus. Numbers in the end of sequence show the amino acid residue numbers of the aligned sequences in polypretein for each virus. Consensus amino acid positions conserved in at least three sequences are boxed. 
(1988). In this study, we report the development of a multiplex RT-PCR method for detecting multiple virus infections in honey bee colonies by utilizing several virus-specific primers. New primers were developed for DWV and SBV such that the PCR products were clearly distinguished in size from the products of BQCV and KBV amplified using previously developed primers (Benjeddou et al., 2001; Stoltz et al., 1995). Our results revealed that the multiplex RT-PCR can simultaneously identify infections of at least four honey bee viruses, namely BQCV, DWV, KBV, and SBV. We found that amplification of each virus template from the multiplex RT-PCR assay coincided with the results we obtained from uniplex RT-PCR assays that were used to detect individual viruses in bees. Variations in the band intensities of PCR fragments from both multitplex RT-PCR and uniplex RT-PCR suggest that there was a difference in concentrations of the coexisting viruses. The discrepancy in concentrations of individual viruses may be the result of competition among the viruses in the honey bee host, though further studies are needed to confirm this assumption.
Our results demonstrated that mixed virus infections in honey bees are quite widespread in nature, as we detected mixed infections of BQCV, DWV, KBV, and SBV in adult worker bees and bee brood. Although virus coinfections have long been recognized in plants and other animals, information on mixed virus infections in honey bees has accumulated very slowly over the last decade. Anderson and Gibbs (1988) first reported infections of $\mathrm{KBV}, \mathrm{SBV}$, and $\mathrm{BQCV}$ in bee colonies and demonstrated that replication of SBV and BQCV could be suppressed by activation of KBV. The genetic study of Evans (2001) showed that KBV and ABPV could infect the same bee, simultaneously. Similar dual viral infections in honey bees have been reported by Hung et al. (1996a,b) and Benjeddou et al. (2001). Despite the fact that honey bees can harbor multiple virus infections simultaneously, gaps still exist in our current knowledge of the effects of such mixed infections on pathogenic processes in honey bees. Whether the viruses infect the same host but occupy separate physiological niches in the bees or infect the bee and share the same microenvironment to compete for host

\section{B. Sequence Alignment of Putative RdRp Domain of Viruses}

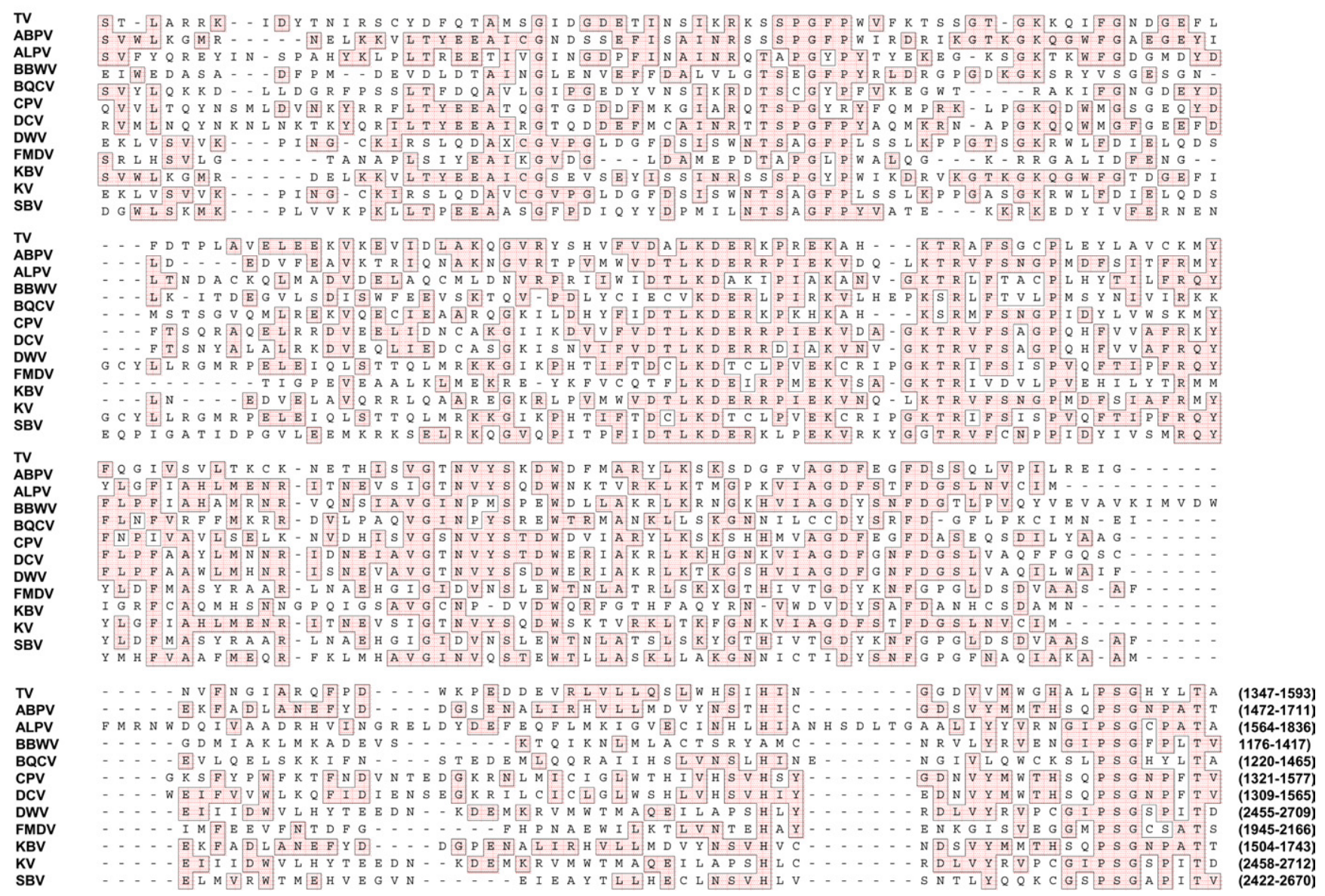

Fig 3. (continued) 


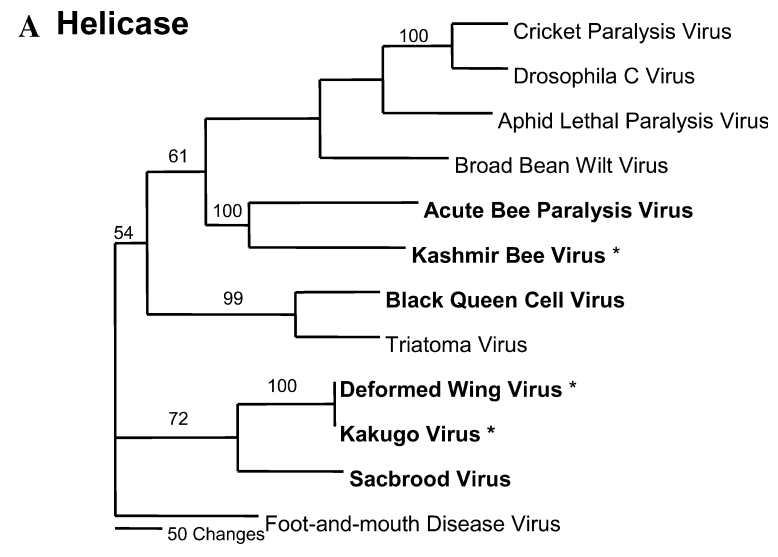

B RdRp

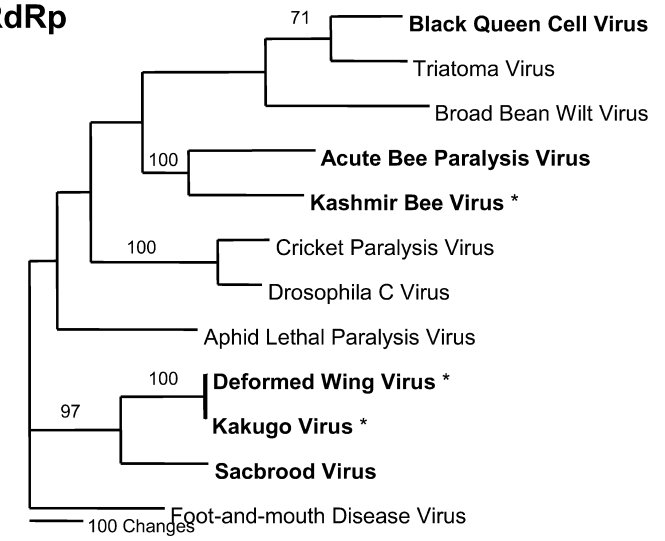

Fig. 4. Phylogenetic trees derived from the putative helicase (A) and RdRp (B) amino acid sequences of the viruses. Helicase and RdRp domains used in the phylogenetic analysis are those shown in Fig. 3. For both figure A and B, amino acid sequences were aligned using the DNASTAR Lasergene software program, MegAlign. Aligned sequences were imported into the phylogenetic analysis program PAUP 4.03. Method of maximum parsimony was used to construct the phylogenetic relationship of viruses. Foot-and-mouth disease virus was used as an outgroup to root the trees. Bar lengths represent 50 inferred character state changes for the tree derived from the helicase domain and 100 inferred character state changes for the tree derived from the $\mathrm{RdRp}$ domain. Branch lengths are proportional to the number of inferred character state transformations. Numbers at each node represent bootstrap values as percentages of 100 and only bootstrap values greater than $50 \%$ are shown. Viruses found in honey bees are shown in bold and honey bee viruses that recently have been sequenced in full are shown in bold and by asterisks.

resources remain to be determined. Moreover, it is not known whether mixed virus infections could lead to genetic recombination between coexisting viruses and whether such recombination could result in the emergence of new viruses. To address these issues, efforts are currently underway to investigate the immunological effects of virus coinfection in honey bees and the degree of genetic heterogeneity in coinfecting viruses.

As an alternative approach, honey bees from colonies identified with multiple virus infection were subjected to analysis by electron microscopy. Though we utilized a purified bee preparation known (by RT-PCR) to con- tain four different viruses, we were unable to distinguish individual viruses since all viral particles appeared morphologically similar. This is in general agreement with previous EM studies of viruses isolated from bees (Bailey and Wood, 1977; Bailey and Ball, 1991) and from bee mites (Kleespies et al., 2000). The separation of different bee viruses from the same preparation is very difficult because of a lack of alternate host, in which virus can be propagated specifically. The development of a technique known as reverse genetics may offer a way to generate the virus specific transcript for manipulation of RNA virus infections at the molecular level. Reverse genetics is a technique to develop infectious virus from complementary cDNA. A stable full-length cDNA clone corresponding to the genome of an RNA virus is constructed and then transcribed in vitro with the use of RNA polymerase to produce RNA transcripts which are replicas of the genomic RNA. This technology is particularly applicable to positive-strand RNA viruses, whose RNA genomes function as mRNA and can result in a productive virus infection upon introduction into bee host or host cells. As a result, a single type of virus can be purified from inoculated hosts or transformed host cells. So far, reverse genetic systems have been developed for a number of positive-stranded RNA viruses (Boyer and Haenni, 1994), including honey bee BQCV (Benjeddou et al., 2002). In the future, we plan to conduct studies to construct infectious transcripts of bee viruses and to evaluate their infectivity in vivo and in vitro, and to locate their distribution in tissues of honey bees by labeling individual constructs.

Molecular phylogenetics of some honey bee viruses was described previously by Evans and Hung (2000). In their report, the phylogenetic relationships of three honey bee viruses with respect to thirteen additional plant and animal viruses were analyzed. As complete genome sequences of more honey bee viruses including $\mathrm{KBV}$, DWV, KV become available in the GenBank, it will be important to add these viruses into the existing phylogenetic framework of honey bee viruses. Here we present a phylogenetic analysis based on putative amino acid sequences of the helicase and $\mathrm{RdRp}$ domains including additional bee viruses that have been sequenced in full. RdRp has often been used for phylogenetic analysis because the $\mathrm{RdRp}$ domain contains sequence motifs that are highly conserved in all positive stranded RNA viruses (Koonin and Dolja, 1993). Phylogenetic analysis using either helicase or RdRp of viruses yielded similar results and reflect genetic divergence among bee viruses. The results showed that $\mathrm{KBV}$, APBV and BQCV formed a common lineage with $\mathrm{TV}, \mathrm{CPV}, \mathrm{DCV}$, and BBWV, suggesting their common evolutionary origin with picorna-like viruses that infect plants, insects, and vertebrate. KBV is closely related to ABPV in the phylogenetic tree as long believed. BQCV tended to group together with KBV and ABPV 
but not closely related to them. DWV, KV, and SBV fell into a separate group with bootstrap value greater than $70 \%(72 \%$ in the phylogenetic tree derived from helicase and $97 \%$ in the phylogenetic tree derived from $\mathrm{RdRp}$ ) in the main node, although DWV and KV are more closely related to one another in the group. Therefore, the result suggested that combined infections of BQCV, DWV, $\mathrm{KBV}$, and SBV in the honey bee likely reflect broad geographic distribution of viruses or virus vectors.

Because of variations in the genome structure of honey bee viruses, the selection of appropriate primers is of crucial importance for specificity of the multiplex RTPCR assay. The method of using universal primers to detect and to subtype viruses may not be applicable for detection of distantly related bee viruses such as BQCV and DWV that were found coinfecting honey bees with the highest frequency in this study.

The development of multiplex RT-PCR reported here will allow simultaneous detection of different viruses in a single reaction, which can save time and reduce the diagnostic cost, thereby contributing to large scale viral disease diagnosis and screening, and aid in determining the epidemiology of bee viral infections.

\section{Acknowledgments}

We gratefully acknowledge Michele Hamilton and Bart Smith for excellent technical assistance, Magaret Dianelt for electron microscopy, and Dawn Gunderson-Rindel for reviewing the phylogenetic work.

\section{References}

Allen, M.F., Ball, B.V., 1995. Characterization and serological relationships of strains of Kashmir bee virus. Ann. Appl. Biol. 126, 471-484.

Allen, M., Ball, B., 1996. The incidence and world distribution of the honey bee viruses. Bee World 77, 141-162.

Allen, M.F., Ball, B.V., White, R.F., Antoniw, J.F., 1986. The detection of acute paralysis virus in Varroa jacobsoni by the use of a simple indirect ELISA. J. Apic. Res. 25, 100-105.

Anderson, D.L., 1984. A comparison of serological techniques for detecting and identifying honeybee viruses. J. Invertebr. Pathol. 44, 233-243.

Anderson, D.L., 1990. Pests and pathogens of the honeybee (Apis mellifera L.) in Fiji. J. Apic. Res. 29, 53-59.

Anderson, D.L., Gibbs, A.J., 1988. Inapparent virus infections and their interactions in pupae of the honey bee (Apis mellifera Linnaeus) in Australia. J. Gen. Virol. 69, 1617-1625.

Bailey, L., 1967. The incidence of virus diseases in the honey bee. Ann. Appl. Biol. 60, 43-48.

Bailey, L., 1976. Viruses attacking the honey bee. Adv. Virus Res. 20, 271-304.

Bailey, L., Ball, B.V., 1991. Honey bee pathology, Second ed. Academic Press, London.

Bailey, L., Wood, R.D., 1977. Two more small RNA viruses from honey bees and further observations on sacbrood and acute beeparalysis viruses. J. Gen. Virol. 37, 175-182.
Bakonyi, T., Farkas, R., Szendroi, A., Dobos-Kovacs, M., Rusvai, M., 2002. Detection of acute bee paralysis virus by RT-PCR in honey bee and Varroa destructor field samples: rapid screening of representative Hungarian apiaries. Apidologie 33, 63-74.

Benjeddou, M., Leat, N., Allsopp, M., Davison, S., 2001. Detection of acute bee paralysis virus and black queen cell virus from honeybees by reverse transcriptase PCR. Appl. Environ. Microbiol. 67, 2384 2387.

Benjeddou, M., Leat, N., Allsopp, M., Davison, S., 2002. Development of infectious transcripts and genome manipulation of black queen-cell virus of honey bees. J. Gen. Virol. 83, 3139-3146.

Boyer, J.C., Haenni, A.L., 1994. Infectious transcripts and cDNA clones of RNA viruses. Virology 198, 415-426.

Chamberlain, J.S., Ranier, J.E., Nguyen, P.N., Caskey, C.T., 1988. Deletion screening of the Duchene muscular dystrophy locus via multiplex DNA amplification. Nucleic Acids Res. 16, 1114111156.

Chen, Y.P., Pettis, J.S., Evans, J.D., Kramer, M., Feldlaufer, M.F., 2004. Molecular evidence for transmission of Kashmir bee virus in honey bee colonies by ectoparasitic mite, Varroa destructor. Apidologie 35 (4), 441-448.

Evans, J.D., Hung, A.C., 2000. Molecular phylogenetics and the classification of honey bee viruses. Arch. Virol. 145, 2015-2026.

Evans, J.D., 2001. Genetic evidence for coinfection of honey bees by acute bee paralysis and Kashmir bee viruses. J. Invertebr. Pathol. 78, 189-193.

Fujiyuki, T., Takeuchi, H., Ono, M., Ohka, S., Sasaki, T., Nomoto, A., Kubo, T., 2004. Novel insect picorna-like virus identified in the brains of aggressive worker honeybees. J. Virol. 78, 1093-1100.

Ghosh, R.C., Ball, B.V., Willcocks, M.M., Carter, M.J., 1999. The nucleotide sequence of sacbrood virus of the honey bee: an insect picornavirus. J. Gen. Virol. 80, 1541-1549.

Govan, V.A., Leat, N., Allsopp, M., Davison, S., 2000. Analysis of the complete genome sequence of acute bee paralysis virus shows that it belongs to the novel group of insect-infecting RNA viruses. Virology 277, 457-463.

Grabenstiner, E., Ritter, W., Carter, M.J., Davison, S., Pechhacker, H., Kolodziejek, J., Boeching, O.I., Derakhshifar, R., Moosbeckhofer, E., Licek, N., Nowotny, 2001. Sacbrood virus of the honeybee (Apis mellifera): rapid identification and phylogenetic analysis using reverse transcription-PCR. Clin. Diagn. Lab. Immunol. 8, 93-104.

Hung, A.C.F., Ball, B.V., Adams, J.R., Shimanuki, H., Knox, D.A., 1996a. A scientific note on the detection of American strain of acute paralysis virus and Kashmir bee virus in dead bees in one US honey bee (Apis mellifera L) colony. Apidologie 27, 55-56.

Hung, A.C.E., Shimanuki, H., Knox, D.A., 1996b. Inapparent infection of acute paralysis virus and Kashmir bee virus in the U.S. honey bees. Am. Bee J. 136, 874-876.

Hung, A.C.F., Peng, C.Y.S., Shimanuki, H., 2000. Nucleotide sequence variations in Kashmir bee virus isolated from Apis mellifera and Varroa jacobsoni. Apidologie 31, 17-23.

Kleespies, R.G., Radtke, J., Bienefeld, K., 2000. Virus-like particles found in the ectoparasitic bee mite Varroa jacobsoni Oudemans. J. Invertebr. Pathol. 15, 87-90.

Koonin, E.V., Dolja, V.V., 1993. Evolution and taxonomy of positivestrand RNA viruses: Implications of comparative analysis of amino acid sequences. Crit. Rev. Biochem. Mol. 28, 375-430.

Leat, N., Ball, B., Govan, V., Davison, S., 2000. Analysis of the complete genome sequence of black queen-cell virus, a picorna-like virus of honey bees. J. Gen. Virol. 81, 2111-2119.

Mansy, F., Brancart, F., Liesnard, C., Bollen, A., Godfroid, E., 1999. A PCR based DNA hybridization capture system for the detection of human cytomegalovirus. A comparative study with other identification methods. J. Virol. Methods 80, 113-122.

Morse, R.A., Calderone, N.W., 2000. The value of honey bee pollination in the United States. Bee Culture 128, 1-15. 
Mayo, M.A., 2002. Virus taxonomy-Houston 2002. Arch. Virol. 147, 1071-1076.

Ribiere, M., Triboulot, C., Mathieu, L., Aurieres, C., Faucon, J.-P., Pepin, M., 2002. Molecular diagnosis of chronic bee paralysis virus infection. Apidologie 33, 339-351.
Rinderer, T.E., Green, T.J., 1976. Serological relationship between chronic bee paralysis virus and the virus causing hairless-black syndrome in the honeybee. J. Invertebr. Pathol. 27, 403-405.

Stoltz, D., Shen, X.-R., Boggis, C., Sisson, G., 1995. Molecular diagnosis of Kashmir bee virus infection. J. Apic. Res. 34, 153-160. 